\title{
ミクロネシア連邦におけるハンセン病事情と 新たな制圧対策
}

\author{
松岡正典* \\ 国立感染症研究所ハンセン病研究センター \\ 〔受付：1997 年 10 月 30 日〕 \\ キーワード：ハンセン病、予防投薬、ミクロネシア連邦、 \\ ピンゲラップ島、カピンガマランギ島
}

南太平洋に位置するナウル共和国において、かって1930年代より始まった非常に激しいハンセン病の 流行があったことが広く知られている。ナウル共和国と国境を接っし、以前はカロリン諸島と呼ばれた ミクロネシ連邦では、当時ナウルからの人の移動に伴って生じたハンセン病の流行の影響により、今もっ て他には見られない高い有病率と多くの新患発生が報告されている。これに対し、WHOを中心とする 新たなハンセン病対策が1996 年より行われている。これらについて紹介をしたい。

\section{地理と歴史}

ミクロネシア連邦は、パプア・ニューギニアの 北方の西太平洋地域に、赤道と北緯 10 度の間に位 置する。東西約 $3,000 \mathrm{Km}$ 、南北約 $1,300 \mathrm{~m} 、 2,978,000$ $\mathrm{km} \mathrm{m}^{2}$ 広大な海域に、およそ 607 の火山島あるいは 隆起珊瑚の島々が散在しているが、陸地総面積は わづか $701 \mathrm{~km} に$ にずない。このうち 65 の島に人が 住み、1996 年の総人口は 108,607 人である。ミク ロネシア連邦は 4 州からなる連邦国家で、西より Yap、Chuuk、Pohnpei、Kos r a eの各州がある (Fig 1)。首都はPohnpei 島の Parikirにある。以前 Chuukはトラック、Phonpeiはポナペとそれぞれ 呼ばれていた1)。

Yapには紀元前 600 年、Chuuk では紀元 0 年に ヒトがすんでいたことが確認されている。スペイ ンによる 1656 年のマリアナ諸島の領有宣言に続 いて、16世紀より植民地支配が始まった。1899年

"Corresponding author:

厂 189 東京都東村山市青葉町 4-2-1

国立感染症研究所ハンセン病研究センター

Tel:0423-91-8211 Fax:0423-94-9092
ドイッに売却され、1914 年第一次世界大戦初頭、 日本が占領し、1919年正式に日本の委任統治領と なった。当時は南洋庁の支庁がトラック、ヤップ、 ポナぺに置かれていた。第二次世界大戦終了後、 1947 年よりアメリカ合衆国の信託統治領を経て、 1986年独立国家となった。1988年より日本と外交 関係を樹立した。

\section{ハンセン病の流行状況}

過去11年間における同国の新患者数、登録患者

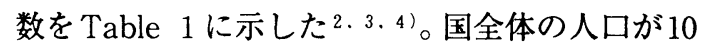
万余りと少数であるためにいずれの時期において も登録患者の絶対数は 1,000 名を超えることはな く、また暫時その数を減じてきたが、1996年の有 病率は依然として $33 / 10,000$ という高い值を示す。 この有病率は世界のどの国における有病率よりも 著しく高く、1996年のWHOのデータ 5)に基けば、 これに続く高い有病率はアフリカのガボンにおけ る18.5であり、また登録患者数の多い上位 2 力国 のインドおよびブラジルでも 6.1 である。 


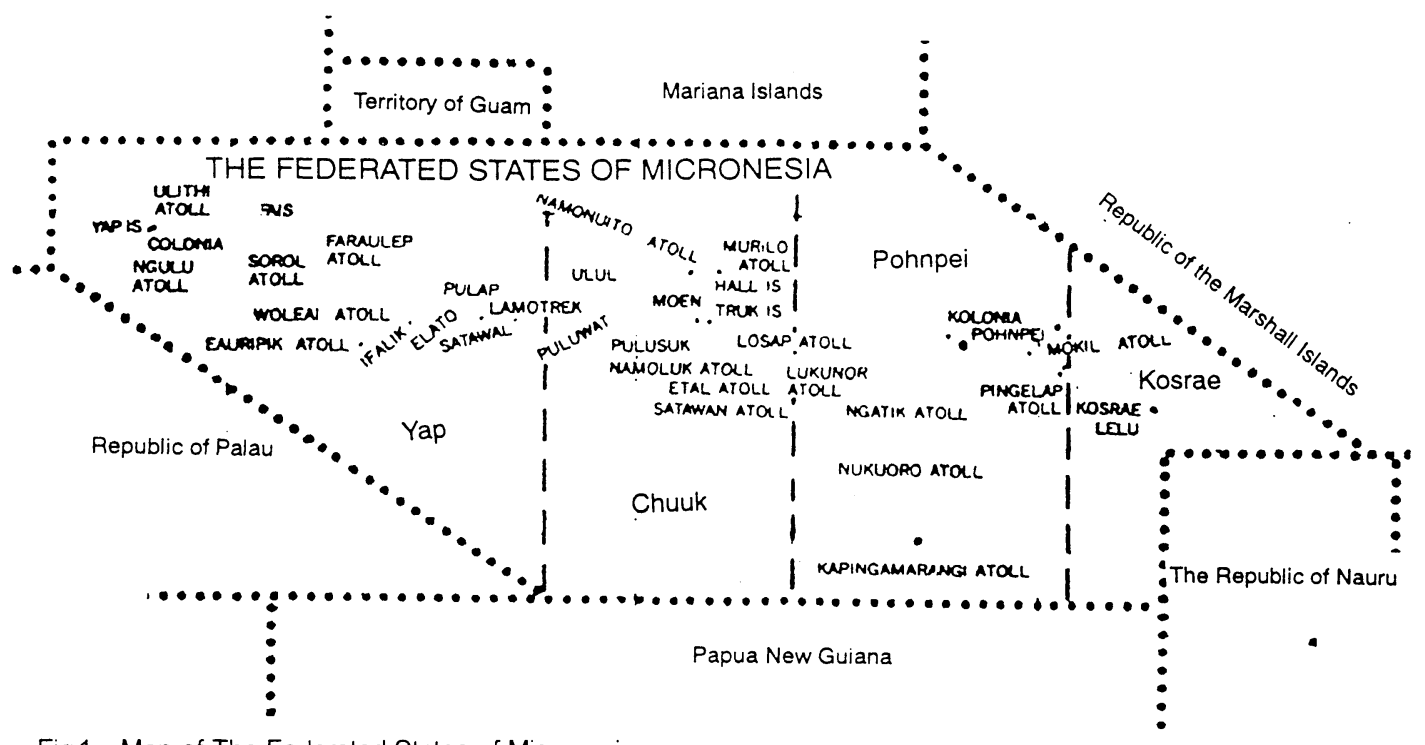

Fig.1. Map of The Federated States of Micronesia

新患者登録数は 1993 年以後、1994 年はやや低 い值を示したがその他の年では著しく高い值を示 し、1996年には 240 名を数え、その発見率は 221 / 100,000である。4 州のうち Yap 州は他の 3 州に 比して流行は低いものの、1996 年の有病率は 11/ 10,000、発見率は $93 / 100,000$ であり、いずれの州 でも他国には見られないハンセン病の流行が続い ている。これらのデータはミクロネシア連邦にお けるハンセン病の流行がWHOによって設定され た有病率が $1 / 10,000$ 以下、新患発見率が $1 / 100,000$ 以下となれば公衆衛生上の問題ではなくなるとし た目標とは大きくかけ離れたものであることを示 している。

Pohnpei 州内では過去に Pingelap 島6、7、8)、 Kapingamarangi 島 $\left.{ }^{9} 、 10\right)$ で特に多くの患者発生 があったことが報告されており、現在の Pohnpei 州での高い有病率も多分にこの影襞を受けている ものと推察される。また、Pingelap島ではD D S による予防投薬が試みられ6、7、8)、その報告にこ の島のハンセン病の歴史と状況が詳しく記載され ている。Pingelap島はPohnpei島の東南東 $260 \mathrm{Km}$ に位置する環礁で陸地面積は僅か $2.5 \mathrm{~km}^{2}$ 以下の小 島である。その住民は1775年にこの島を謷った台 風により大きな被害を受け、30名の島民が生き 残った。現在の住民はその僅かな人々を先祖とす る子孫であるという遺伝学的な特徴を示す。その 後の人口増加により、1918年と 1956年にPohnpei
島への一部住民の移住が行われ、そこで二つの集 落を形成した。Pohnpei島に移住した人々の Pohnpei 島民との交流は少なくPingelap島住民と の密接な交流のもとに生活をしていることから、 報告に見られる調査はこの両地域をあわせて実 施、報告されている。

Pingelap島に最初にハンセン病がもたらされた のは、1918年にナウルに在住した際に䍜患したギ ルバート島の女性によるとされる7)。1953年以前 にはこの地域について、ハンセン病についての調 査は全く行われなかった。1953 年にSalmon が Pingelap 島に在住する島民についてのみ調査を 行った際には45名の患者を確認した6)。全島民を 対照とした調査が1967年に実施され、その年の人 口は 1,500名でPohnpei 島の 2 集落のそれぞれの 人口は550名と 250 名であった、62名のactive case および 37 名の inactive caseが確認された。有病 率はactive caseのみでは41/1,000であり、全て含 めると66/1,000であった。1969年に行ったより正 確な調査の結果によると、患者数は111名であり、 内68名が active case であった。1963年から 1969 年までの新患発生率は $7.3 / 1,000 /$ 年であった $6.71 。$

Pingelap 島におけるハンセン病流行に対し、 1967 年から 1970 年にDDSによる患者の治療と未 感染の全島民を対照とした予防投薬が実施され、

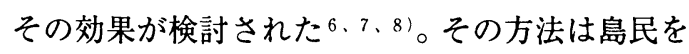
以下の群に分けて実施された。1) すべての患者 
と 6 才以上の住民に対してはDADDSを $1.5 \mathrm{~m} \ell(225$ $\mathrm{mg}) 、 3$ 年間 75 日毎に合計 15 回筋肉内注射を行い、 2) 6 ケ月以上 5 才までの子供には $1.0 \mathrm{ml}(150 \mathrm{mg})$ を同様に投与した。3）1968年 10 月までに生ま れた子供に対しては生後 6 ケ月に投薬を開始し、 前 2 者と同じく 1970 年まで行われた。1976年ま での追跡調査 ${ }^{81}$ では 1 および 2 群での年間の新患 発生率は $2 / 1,000$ に減少した。第 3 群の子供に 1973年より新患の增加が見られ、1973年、1974年、 1976年にそれぞれ 1、2、7 名がハンセン病と診 断された。この地域での患者に対しては1975より rifampicinによる治療が導入されている。Douglas らの報告"11によれば1982年に実施した738名の一 般住民を対照とした ELISAによる抗体検査では 43\%の住民が抗体陽性であった。1976年以後のこ の地域におけるハンセン病の患者の実態について は報告が無く、現在の状況は不明である。

Pohnpei 州においてはもう一個所非常に高い有 病率を示した地域として、Kapingamarangi 島が 知られている。同島はPohnpei島の南西約 $800 \mathrm{Km}$ に位置し、33の島を含む環礁で礁湖面積は $57 \mathrm{~km} 、$

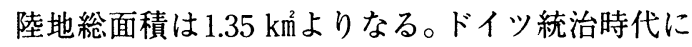
Kapingamarangi 島から Pohnpei 島に移住した住 民がPorakiet 地区に集落を形成して居住し、 Kapingamarangi 島に住む人々と交流を保ってい る。彼らはポロネシア人であり、他のミクロネシア 連邦の住民とは人種を異にする。したがって Kapingamarangi住民におけるハンセン病のデータ はこの 2 個所について合せて報告されている ${ }^{9.10) 。 ~}$

Kapingamarangi の住民でのハンセン病流行は、
1962 年から 1967 年にかけ Porakiet 地区に住む 8 才 の少女と 47 才の男性が Porakiet の北に隣接する Sokes 島で Pingelap の住民より感染を受けたと推 定される症例と、2 名の兄弟が学校で感染をうけ た症例に端を発するといわれている。Sokes島には 先に記した Pingelap 島の島民が Pohnpei 島に形成 した集落のうちの一つがあった。その後 1966 年、 1969 年、1970 年、1974 年、1975年に各々 1 名の新 患発生が有り、1977 年には 2 名、1978年と 1979 年 にはそれぞれ 3 名が記録されている。1980年より 積極的な症例発見が開始され、1980 年には 5 例、 1981 年には 26 例、更に 1982 年には 90 名の新患者 が見出された (Fig. 2)。1982年末における人口は約 1,100 名であり、累積有病率は $12.5 \%$ に達した。こ のうち小览が $65 \%$ を占め、最小年齢は 2 才の症例 であった。1982年に行ったELIS Aによる755名の 一般住民の抗体検査では $43 \%$ が陽性であった ${ }^{11}$ 。

Pohnpei 州のハンセン病患者のうち Kapingamarangi の住民が占める割合についで Table 2 に示した ${ }^{12)}$ 。1981 年の 26 名、1982 年での 90 名に 比し、著明な滅少が見られている。しかしながら 1996年の Kapingamarangiの住民は多く見皘もっ ても2,000名未満であると考えられるので新患発 生率は 300/100,000 以上であると推察され、依然 として高い值を示している。Pingelapの住民がど れくらいの割合を占めるのかは不明であるが、得

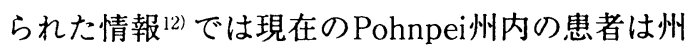
内全域に散在するということより、現在Pingelap の住民には過去に見られたような多くの患者発生 はないものと考えられる。

Fig.2. Time trend of new cases in Pingerap people.

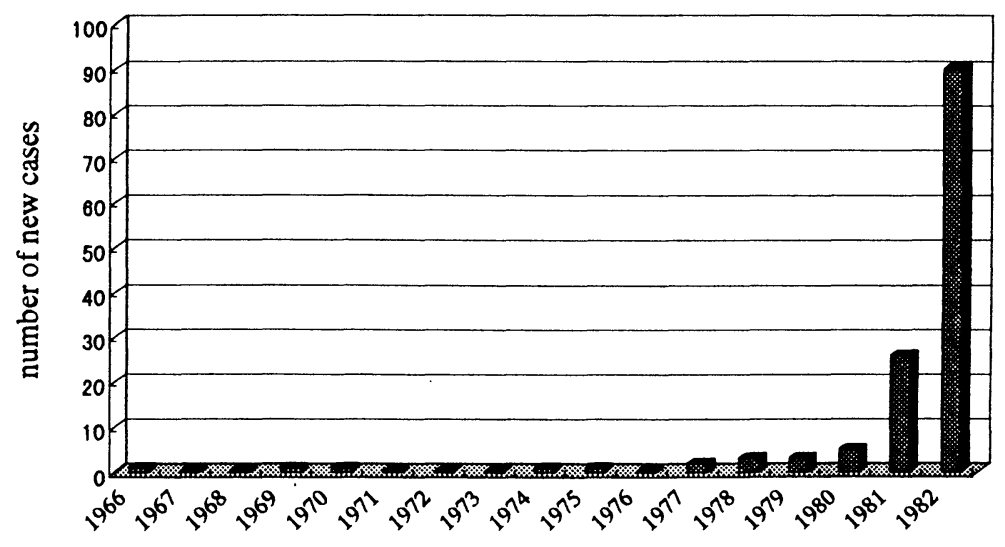


Chuuk 州ならびに Kosrae 州でも高い有病率が 示されているが、Chuuk 州へは1930 年代にナウ ルのリン鉱石採取に従事した人の帰国に伴って持 ち込まれたといわれる13)。またKosrae州では1960 年代よりハンセン病の流行が始まった考えられて いる ${ }^{12)}$ これらの州のうちChuuk 州ではWeno地 区に特に多くの患者発生が見られ、Chuuk州の患 者の半数以上を占める (Table 3) ${ }^{13)}$ 。この地区 の住民数が不明な為、推測に過ぎないがWeno地 区における新患発生数、有病率ともに相当高いこ とが考えられる。

\section{予防投薬を併用した 新たなハンセン病対策の開始}

ミクロネシア連邦では 1983 年より W H O によ る多剂併用療法が導入され、1990 年には既に 100\%の実施率であった。しかしながらその後も 多くの患者発生が見られることから、WHOは 1996年より同国において、予防投薬に基く新たな ハンセン病対策を開始した ${ }^{14 、 15) 。 ~}$

新規ハンセン病対策はミクロネシア政府、 WHO 並びに笹川記念保健協力財団によって組織 され、1996,年 1 月から 3 月までを準備期間、3 月 から12月を対策実施期として開始された。1997年 を 2 年度とし、その後 7 年間の観察期が予定され ている。

対策の概要は以下のとおりである。国内 4 州に おいてより一層の患者発見に努め、多剂併用療法 （MDT）による治療を徹底させる。更に一般住民 に対し、BCG接種と合わせ、下記の予防投薬をそ れぞれ 1 回行う。

成人（MDT、DDS 単独治療修了者も含む）

$\begin{array}{ll}\text { rifampicin } & 600 \mathrm{mg} \\ \text { ofloxacin } \quad 400 \mathrm{mg} & \\ \text { minocyclin } & 100 \mathrm{mg} \\ \text { 小児 }(15 才 以 下) \\ \text { rifampicin } \quad 25 \mathrm{mg} / \mathrm{kg}\end{array}$

以上の対策により初年度では新患発生数を $80 \%$ 滅少しうると見込まれ、2000 年には制圧目標を達
成することができると期待されている。

以上ミクロネシア連邦におけるハンセン病事情 と新たな対策の概要について記した。多剤併用療 法が導入され、既に数年を経た今日でも同国にお いてなぜ今もって多くの新患発生が見られるの か、ハンセン病の発生が社会経済的要因によって 影響を受けるのであれば、特にWeno 地区に見ら れる多くの患者発生に関与する因子は何なのか。 また、かってのPingelap あるいはKapingamarangiにおける激しい流行は何故ゆえに終息に 向かったのか。その解明はハンセン病対策を考え るうえで格好のモデルと思われる。広大な海域に 島々が散在するこの国の地理的条件と社会基盤の 整備状況を考えると、ハンセン病対策に限らず、 交通の便をはじめとするあらゆる面での困難が伴 うことは想像に難くない。今回の予防対策がどの 程度実効を示すのか大変興味のあるところであ る。過去の Pingelap おける同様の試みは、後に 小児を中心とした新たな患者の発生を止めること はできなかった。これはDDS単独であったたこと が原因であったのか、あるいはこの種の手法では 対処できない感染源が存在するのか等の疑問が持 たれる。これに対しても今回の企画の結果により 答えが示されるものと期待している。

われわれは最近、らい菌の遺伝子内には 6 塩基 が直列する部位があり、その繰り返し数が 4 コ ピーの株と 3 コピーのものがあり、菌株によって 異なる塩基配列を有することを見出した ${ }^{16)}$ 。今ま でらい菌には型別に利用しうる遺伝子の多様性は ないとされてきたが、この部位の検索により、分 離されるらい菌は少なくとも 2 群に分類すること ができる。国内で分離された株では地域によりそ の異同に偏りがあることが見られた。比較的流行 の由来がはっきりしているミクロネシア連邦のら い菌はどのような塩基配列を持っているのか。ナ ウルに存在するらい菌と同じプロフィールを有す るのか、更にナウルでの流行株とその由来地とさ れる地域で分離されるらい菌とではどのような DNAの相同性が示されるのか、いずれも大変興 味深く思われる。 
Table 1. Time trend of the leprosy in Federated States of Micronesia (FMS).

\begin{tabular}{lrrrrc}
1986 & & & & \\
\hline State & Population & $\begin{array}{c}\text { New } \\
\text { cases }\end{array}$ & $\begin{array}{c}\text { Registered } \\
\text { cases }\end{array}$ & $\begin{array}{c}\text { Incidence } \\
\text { rate } \\
1100,000\end{array}$ & $\begin{array}{c}\text { Prevalenc } \\
\text { e } \\
110,000\end{array}$ \\
\hline Yap & 11,322 & 5 & 34 & 44 & 30 \\
Kosrae & 6,668 & 12 & 57 & 179 & 85 \\
Chuuk & 47,724 & 46 & 293 & 96 & 61 \\
Pohnpei & 28,820 & 108 & 486 & 374 & 169 \\
\hdashline FMS $^{\star}$ & $\mathbf{9 4 , 5 3 4}$ & 171 & 870 & 182 & 92 \\
\hline
\end{tabular}

\begin{tabular}{lrrrrc}
1993 & & & & \\
\hline State & Population & $\begin{array}{c}\text { Now } \\
\text { cases }\end{array}$ & Rogistered & $\begin{array}{c}\text { Incidence } \\
\text { rate } \\
\text { roo,000 }\end{array}$ & $\begin{array}{c}\text { Prevalence } \\
10,000\end{array}$ \\
\hline Yap & 11.239 & 2 & 9 & 18 & 8 \\
Kosrae & 7,734 & 18 & 33 & 233 & 43 \\
Chuuk & 49,934 & 77 & 147 & 145 & 29 \\
Pohnpei & 34,161 & 123 & 173 & 356 & 50 \\
\hdashline FMS & 103,068 & 220 & 362 & 213 & 35 \\
\hline
\end{tabular}

\begin{tabular}{|c|c|c|c|c|c|}
\hline Yap & 11,714 & 3 & 27 & 26 & 23 \\
\hline Kosrae & 6,901 & 10 & 27 & 144 & 39 \\
\hline Chuuk & 49,365 & 107 & 347 & 216 & 70 \\
\hline Pohnpei & 29,800 & 57 & 450 & 191 & 151 \\
\hline FMS & 97,780 & 177 & 851 & 182 & 87 \\
\hline
\end{tabular}

\begin{tabular}{lrrrrr}
1994 & & & & \\
\hline Yap & 1,356 & 1 & 6 & 9 & 5 \\
Kosrae & 7,834 & 16 & 35 & 204 & 45 \\
Chuuk & 50,294 & 42 & 127 & 84 & 25 \\
Pohnpei & 34,161 & 37 & 122 & 106 & 35 \\
\hdashline FiMS & 103,645 & 96 & 290 & 92 & 28 \\
\hline
\end{tabular}

\begin{tabular}{lrrrrr}
1988 & \multicolumn{1}{l}{} \\
\hline Yap & 12,117 & 0 & 14 & 0 & 30 \\
Kosrae & 7,121 & 11 & 28 & 154 & 85 \\
Chuuk & 51,053 & 37 & 263 & 72 & 61 \\
Pohnpei & 30,819 & 39 & 477 & 126 & 169 \\
\hline FMS & 101,110 & 87 & 872 & 86 & 92 \\
\hline
\end{tabular}

\begin{tabular}{|c|c|c|c|c|c|}
\hline Yap & 11,474 & 1 & 6 & 9 & 5 \\
\hline Kosrae & 7,934 & 9 & 22 & 113 & 28 \\
\hline Chuuk & 50,654 & 91 & 157 & 178 & 31 \\
\hline Pohnpei & . 35,383 & 52 & 103 & 147 & 29 \\
\hline FMS & 105,445 & 153 & 288 & 145 & 27 \\
\hline
\end{tabular}

\begin{tabular}{|c|c|c|c|c|c|}
\hline Yap & 12,531 & 1 & 14 & 8 & 11 \\
\hline Kosrae & 6,838 & 4 & 19 & 58 & 27 \\
\hline Chuuk & 52,907 & 42 & 193 & 79 & 36 \\
\hline Pohnpei & 31,737 & 49. & .432 & 154 & 136 \\
\hline FMS & 104,013 & 96 & 658 & 92 & 63 \\
\hline
\end{tabular}

\begin{tabular}{|c|c|c|c|c|c|}
\hline Yap & 11818 & & & 93 & \\
\hline Kosrae & 8,172 & 10 & 21 & 122 & 26 \\
\hline Chuuk & 52,173 & 98 & 158 & 187 & 30 \\
\hline Pohnpei & 36,444 & 121 & 170 & 332 & 46 \\
\hline FMS & 108,607 & 240 & 362 & 221 & 33 \\
\hline
\end{tabular}

\begin{tabular}{lllll}
1990 & & & & \\
\hline FMS & 80 & 628 & 79 & 62 \\
\hline & & & & \\
1991 & & & & \\
\hline FMS & 84 & 601 & 81 & 48 \\
\hline
\end{tabular}

\begin{tabular}{|c|c|c|c|c|c|}
\hline Yap & 11,121 & 1 & 11 & 9 & 10 \\
\hline Kosrae & 7,635 & 10 & 25 & 131 & 33 \\
\hline Chuuk & 49,573 & 47 & 157 & 95 & 32 \\
\hline Pohnpei & 34,161 & 32. & 156 & 94 & 46 \\
\hline FMS & 102,490 & 90 & 349 & 88 & 34 \\
\hline
\end{tabular}

Table 2. New cases in Kapingamarangi people and Ponpei State.

\begin{tabular}{cccc}
\hline Year & $\begin{array}{c}\text { Porakiet } \\
\text { village }\end{array}$ & $\begin{array}{c}\text { Kapingamarangi } \\
\text { atoll }\end{array}$ & $\begin{array}{c}\text { Pohnpei State } \\
\text { (total) }\end{array}$ \\
\hline 1992 & 1 & 1 & 32 \\
1993 & 2 & 9 & 123 \\
1994 & 8 & 3 & 37 \\
1995 & 0 & 5 & 52 \\
1996 & 1 & 5 & 121 \\
\hline
\end{tabular}

Table 3. High incidence at Weno municipality in Chuuk State.

\begin{tabular}{ccc}
\hline Year & $\begin{array}{c}\text { New cases in } \\
\text { Weno }\end{array}$ & $\begin{array}{c}\text { New cases in } \\
\text { Chuuk State (total) }\end{array}$ \\
\hline 1992 & 31 & 47 \\
1993 & 16 & 77 \\
1994 & 9 & 42 \\
1995 & 40 & 91 \\
1996 & 75 & 98 \\
\hline
\end{tabular}




\section{謝 辞}

本稿作成にあたり、笹川記念保健協力財団、Dr. Lepold Blanc (WHO Regional office for the western pacific), Mrs. Lerina Nena (TB/Leprosy program manager)、 Dr. Robert M. Worth (Pacific health research institute)の各位より貴重な資料の 提示を受けた。記して謝意を表します。

\section{文 献}

1.太平洋諸島百科事典太平洋学会編 原書房

2 . Leprosy program monthly report from the states. Department of Health Services, Federated States of Micronesia

3. World Health Organization Regional Office for the Western Pacific: Epidemiological review of leprosy in the western pacific region 1982-1995. (1996)

4. Sasakawa Memorial Health Foundation: SMF/MDT series 2, Leprosy profiles with special attention to MDT implementation. (1991)

5 . World Health Organization: World epidemiological record. (1996)

6. Salmon N. R., Rorth R. M. Jano B., Fasal P. and Shepard C. C.: Acedapson in leprosy chemoprophylaxis: Field trial in three highprevarence villages in microneisa. Int. J. Lepr. 40 40-47 (1972)

7. Russell D. A., Worth R. M., Jano B., Fasal P. and Shepard C. C.: Acedapson in the preventive treatment of leprosy. Lepr. Rev. 44:192-
195 (1973)

8. Russell D. A., Worth R. M., Jano B., Fasal P. and Shepard C. C.: Acedapson in the prevention of leprosy: Field trial in the three high prevalence villages in Micronesia. Am J. Trop. Med. Hyg. 28 559-563 (1979)

9. Worth R. M., Douglas J. T., Murry C., Liebel M. and Liebel E.: A "Virgin - Soil" leprosy endemic Polynesian population. Int. J. Lepr. 52 740 (1984)

10. Liebel M. D. and Liebel E. B.: Social and demographic aspects of a leprosy epidemic on a polynesian atoll: Implications of pattern. Int. J. Lepr. 55 468-480 (1987)

11. Douglas J. T. and Worth R. M.: Field evaluation of an ELISA to detect antibody in leprosy patients and their contacts. Int. J. Lper. 52 26-33 (1984)

12. Lerna J. Nena: TB/Leprosy program Manager Department of Health Services, Federated States of Micronesia 私信

13. Worth R. M.: Pathific Health Research Institute. Honolulu Hawaii 私信

14. Information unit World Health Organization, Regional Office for the Western Pacific: WHO Press release 16 March 1996

15. Pretrick E.: Special action project for the elimination of leprosy in Federated State of Micronesia. Department of Health Services, Federated States of Micronesia.

16. 松岡正典、柏原嘉子、福富康夫: ヌードマウス 足蹠内において低い增殖を示すらい菌の例。 Jpn. J. Lepr. 6634 (1997) 


\title{
High Prevalence of Leprosy in the Federated States of Micronesia and Special Project for the Elimination.
}

\author{
Masanori Matsuoka* \\ National Institute for Infectious diseases \\ Leprosy Research Center
}

〔Received 31 Oct 1977〕

Key words: Leprosy, Chemoprophylaxis, The Federated States of Micronesia,

Pingelap atoll, Kapingamarangi atoll.

Leprosy in Federated States of Micronesia is still endemic with incidence rate 221/100,000 and prevalence $33 / 10,000$ in 1996 . The disease was introduced by the patients from Nauru. Epidemic of the disease was observed in Pingelap during the 1960's and Kpingamarangi since1966.

Special project for the elimination of the disease by the chemoprophylaxis was launched in 1996. The preventive therapy is consist of one dose of an association of 3 antibiotics (rifampicin, cfloxacine and minocyclin) for adults and rifampicin alone for children. The project is completed for two years and followed by evaluation for 6 years. It is expected to reach the elimination level before year 2000 .

\footnotetext{
*Corresponding author:

Leprosy Research Center, National Institute of Intectious Diseases, 4-2-1 Aoba-cho, Higashimurayama-shi, Tokyo 189 , Japan.

Tel:0423-91-8211 Fax:0423-94-9092
} 